\title{
ANALISIS JARINGAN KOMUNIKASI UNTUK MENUNJANG KEGIATAN PEMASARAN PADA INDUSTRI KECIL
}

\author{
Oleh: \\ Hamidah Nayati Utami ${ }^{*)}$
}

\begin{abstract}
Small industry marketing corelated with comunication process. There are communication process between consumer and producer. The situational factors are support the communication process in group. This situations are comnunication network, comnunication behavior, group cohessivity, size of group. This research aimed to describe communication process and marketing activity on small industry group of ceramics, and to examine the correlation of communication process and marketing activity on small industry group of ceramics. This study was conducted the craftsmen of ceramics at Dau district, Malang Regency. Sample taken with simple random sampling method. Survey and interview technique were implemented among 25 craftsmen. Data was analyzed by using communication network analysis and tau Kendall. The results indicated that the craftsmen had a high level of individual connectedness, a medium level of Individual Integration, but Individual Diversity was low. The level of intensity of craftsman marketing activity was low. The results indicated that of individual connectedness, a medium level of Individual Integration, but Individual Diversity were low were correlated with craftsmen's activity in promotion, product determining, placement, and pricing.
\end{abstract}

Keywords: Marketing, Communication Network, Ceramics Craftsman, Small Industry.

\section{PENDAHULUAN}

Latar Belakang

Industri kecil dapat mempercepat pemerataan pertumbuhan ekonomi karena dapat menyerap tenaga kerja dalamjumlah yang besar (padat karya) dan menjadi penyumbang Pendapatan Asli Daerah yang cukup signifikan (kasus kota pasuruan pemasukan dari sektor Industri kecil sebesar Rp 5 Milyar per tahun). Pada beberapa jenis produk, hasil produksi industri kecil di bidang pangan, sandang, kulit, kimia dan bahan bangunan, kerajinan dan umum prospektif untuk ekspor. (Hubeis, 1997) Oleh karena itu dalam rangka otonomi daerah hendaknya pemerintah perlu memberikan perhatian yang lebih optimal guna meningkatkan produktivitas sektor ini. 
Kegiatan pemasaran menjadi ujung tombak keberhasilan kelompok industri kecil, karena dari kegiatan inilah akan dapat diperoleh pendapatan. Sehingga salah satu tolok ukur keberhasilan kelompok adalah seberapa jauh volume penjualan dan pangsa pasar yang dapat diraih oleh industri kecil. Kegiatan pemasaran tidak bisa terlepas dari proses komunikasi, baik itu antara produsen dengan konsumen maupun antara individu yang ada dalam unit usaha. Proses komunikasi antar individu yang ada dalam kelompok memiliki relevansi dengan keberhasilan kelompok, karena dengan komunikasi yang efektif informasi akan dapat diterima dengan baik oleh anggota, dan tidak dapat dipungkiri bahwa informasi sangat dibutuhkan dalam dunia usaha termasuk di dalamnya untuk industri kecil. Salah satu faktor yang mendukung efektifitas proses komunikasi adalah kondisi suasana yang terbangun dalam kelompok tersebut. Kondisi ini dapat dilihat dari jaringan komunikasi, cara berkomunikasi dan menyampaikan gagasan, cara merespon, kemampuan mendengar, kohesivitas kelompok maupun ukuran kelompok. Jaringan komunikasi menentukan bagaimana mereka berhubungan, serta dengan saluran apa informasi dapat diterima individu.

Oleh karena itu penelitian yang terkait dengan kegiatan kelompok dalam rangka mencapai keberhasilan industri kecil perlu dilakukan untuk menunjang upaya pengembangan masyarakat, sehingga pendekatan kelompok dapat digunakan sebagai salah satu pertimbangan dalam melakukan pembinaan pada industri kecil kecil menuju kemandirian dan kemajuan usaha.

\section{Rumusan Masalah}

1. Bagaimana jaringan komunikasi yang terdapat dalam kelompok sentra industri kecil keramik?

2. Bagaimana gambaran kegiatan pemasaran pada kelompok industri kecil keramik?

3. Sejauhmanakah hubungan antara jaringan komunikasi pengrajin dengan kegiatan pemasaran kerajinan? 


\section{Tujuan}

1. Untuk mengetahui jaringan komunikasi yang terdapat dalam kelompok sentra industri kecil keramik.

2. Untuk mengetahui gambaran kegiatan pemasaran pada kelompok Industri Kecil Keramik.

3. Untuk menjelaskan hubungan antara jaringan komunikasi pengrajin dengan kegiatan pemasaran kerajinan.

\section{Hipotesis}

Berdasarkan teori-teori dan hasil penelitian yang telah dikaji, maka penelitian ini merumuskan model dan rumusan hipotesis sebagai berikut:

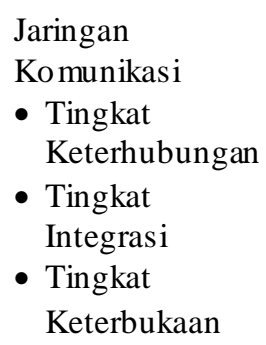

Gambar 1. Model Hipotesis

Diduga terdapat hubungan yang nyata jaringan komunikasi pengrajin (tingkat keterkaitan, tingkat integrasi dan tingkat keterbukaan) dengan Kegiatan pemasaran kerajinan (penentuan jenis produk, penentuan harga, penentuan lokasi dan kegiatan promosi)

\section{Metode Penelitian}

Penelitian ini dilaksanakan di sentra industri Kecil Keramik Kecamatan Dau Kabupaten Malang. Berdasarkan hasil pengamatan pada saat penelitian, jumlah pengrajin keramik di Sentra Industri Kecil Keramik Kecamatan Dau yang menjadi responden sebanyak 25 orang. Data dianalisis dengan (1) analisis jaringan komunikasi, dan (2) Analisis korelasi untuk mendapatkan informasi hubungan antar variabel dan menguji hipotesis. Dengan analisis statitistik nonparametrik tau Kendall. 


\section{HASIL DAN PEMBAHASAN}

\section{Deskripsi Jaringan Komunikasi pada Komunitas Industri Kecil}

Pengrajin keramik di dusun Semanding mengelompok hingga terbentuk beberapa klik. Dasar pembentukan klik adalah adanya ikatan persaudaraan karena sebagian besar pengrajin adalah penduduk yang telah secara turun temurun tinggal di lokasi ini dan bahkan beberapa diantaranya memiliki hubungan keluarga. Hingga wajar apabila mereka membentuk klik yang mempunyai hubungan yang erat. Dalam pembentukan klik ini tidak terbentuk secara sengaja artinya pembentukan klik yang terjadi memang terjadi begitu saja tanpa disadari oleh mereka. Dapat dikatakan pembentukan klik itu merupakan perwujudan "rasa atau perasaan" yang terjalin diantara mereka, baik karena mereka bersaudara maupun karena menekuni bidang kerajinan yang sama.

Jaringan komunikasi terbentuk karena adanya hubungan-hubungan komunikasi antar individu pada proses komunikasi dalam sistem. (Bebee, 1994) Selanjutnya hubungan antar individu tersebut dapat terjadi secara langsung maupun tidak langsung.

Pada komunitas pengrajin keramik, terdapat beberapa pasangan pilihan komunikasi pada saat membicarakan pemasaran produk, yang terdiri dari 1 hingga 5 orang pasangan komunikasi. Pada Tabel 1 menunjukkan bahwa pada kelompok pengrajin di sentra industri keramik di Kecamatan Dau memilih hubungan komunikasi dengan 1 hingga 5 orang pasangan komunikasi. Artinya semua anggota kelompok melakukan interaksi dengan anggota lainnya dengan memilih paling sedikit 1 orang untuk melakukan komunikasi atau pertukaran informasi tentang pemasaran keramik. Jumlah pilihan komunikasi yang paling besar adalah 4 orang sebanyak 36 persen. Hal ini menujukkan bahwa anggota kelompok sangat antusias dalam mencari informasi tentang pemasaran keramik.

Sosiogram yang digambarkan pada gambar 2 menunjukkan bahwa ketua kelompok dipilih sebagai pasangan komunikasi oleh sebagian besar anggoat kelompok (89\%) hanya dua responden yang tidak memilih ketua kelompok sebagai pasangan komunikasinya. Anggota merasa yakin bahwa ketua kelompok 
merupakan sumber informasi yang dapat dipercaya. Berikut ini perbandingan pilihan hubungan komunikasi dan arah hubungan komunikasi.

\section{Tabel 1. Distribusi Responden Menurut Pilihan Hubungan Komunikasi dan Arah Hubungannya}

\begin{tabular}{|c|c|c|c|}
\hline Deskripsi & Kategori & $\begin{array}{l}\text { Jumlah } \\
\text { individu }\end{array}$ & $\%$ \\
\hline \multirow[t]{5}{*}{$\begin{array}{l}\text { Pilihan hubungan } \\
\text { komunikasi }\end{array}$} & $\begin{array}{ll}\begin{array}{l}\text { Memilih } \\
\text { orang }\end{array} & 1 \\
\end{array}$ & 2 & 8 \\
\hline & $\begin{array}{ll}\text { Memilih } & 2 \\
\text { orang }\end{array}$ & 3 & 12 \\
\hline & $\begin{array}{l}\text { Memilih } 3 \\
\text { orang }\end{array}$ & 8 & 32 \\
\hline & $\begin{array}{ll}\begin{array}{l}\text { Memilih } \\
\text { orang }\end{array} & 4 \\
\end{array}$ & 9 & 36 \\
\hline & $\begin{array}{ll}\begin{array}{l}\text { Memilih } \\
\text { orang }\end{array} & 5 \\
\end{array}$ & 2 & 8 \\
\hline \multirow{2}{*}{$\begin{array}{l}\text { Arah Hubungan } \\
\text { Komunikasi }\end{array}$} & Satu arah & 38 & 76 \\
\hline & Dua arah & 12 & 24 \\
\hline
\end{tabular}

Kegiatan pemasaran produk keramik yang dilakukan pengrajin melalui proses komunikasi yang memiliki arah hubungan komunikasi seperti terlihat pada Tabel 1, memperlihatkan bahwa sebagaian besar responden melakukan hubungan komunikasi searah $(76 \%)$. Hal ini berarti responden hanya memilih orang-orang tertentu saja sebagai pasangan komunikasi dalam mencara informasi terkait dengan pemasaran keramik, sedangkan orang yang terpilih tersebut tidak memilih kembali orang yang memilihnya sehingga tidak terjadi komunikasi dua arah atau saling memilih. Hal ini dimungkinkan karena orangorang yang dianggap sebagai sumber informasi benar-benar dapat memberikan informasi yang akurat dan lengkap. Berdasarkan pengamatan di lapangan, orang-orang tempat bertanya anggota kelompok adalah orang yang mereka anggap mempunyai dan menguasai informasi tentang pemasaran keramik baik itu lokasi, bentuk keramik maupun lokasi berjualan, dimana dalam kelompoknya berperan sebagai opinian leader. Komunikasi yang bersifat konvergen terjadi pada saat tercapainya pengertian bersama diantara pengrajin dalam kegiatan pemasaran keramik, baik memlalui hubungan komunikasi 
searah maupun komunikasi dua arah. Hubungan komunikasi satu arah dan dua arah dapat dilihat lebih lanjut pada sosiogram pada Gambar 2.

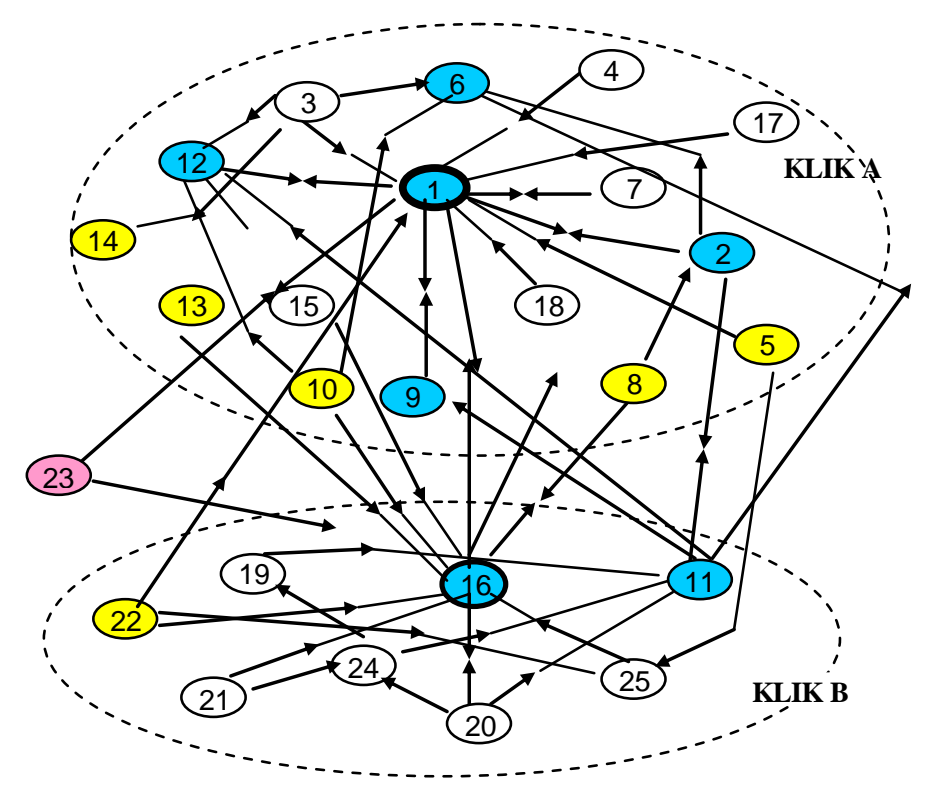

Gambar 2. Hubungan komunikasi satu arah dan dua arah

\section{Peranan individu dalam jaringan komunikasi}

Jika seorang individu dipilih oleh sejumlah inidvidu lain dalam suatu jaringan komunikasi melebihi jumlah rata-rata pilihan yang diterima, maka individu tersebut dikatakan pemuka pendapat (opinion leader). Dalam penelitian ini, individu yang menjadi opinion leader adalah individu yang mempunyai angka pilihan yang diterima melebihi angka rata-rata pilihan yang diterima pada setiap kelompok. Angka pilihan komunikasi rata-rata adalah 3,28. responden yang menjadi opinion leader pada sentra industri kecil keramik adalah sebanyak 7 orang (28\%) yaitu responden 1,2,6,9,11,12 dan 16 .

Ketua kelompok berperan sebagai opinion leader, disamping itu ada opinion leader yang tidak ditunjuk secara formal oleh kelompoknya dan dianggap sebagai opinion leader oleh anggota-anggotanya. Berdasarkan pengamatan di lapangan, mereka yang dianggap sebagai opinion leader umumnya memiliki kekosmopolitansi yang tinggi, memiliki status sosial yang tinggi, lebih aktif 
mencari ke luar sistem, lebih intensif berhubungan dengan konsumen maupun sumber informasi lainnya. Hal ini sesuai dengan pendapat Roger (1983), Gonzales dalam Jahi (1993) yang menyatakan bahwa opinion leader memiliki sejumlah atribut dan kelebihan dibandingkan anggota lainnya dalam sistem, kelebihan tersebut antara lain pendidikan formal yang lebih baik, status sosial ekonomi yang lebih tinggi dan kosmopolitansi yang lebih tinggi.

Peran komunikasi lainnya yaitu bridge dan liaison seperti terlihat dalam Gambar 2. Bridge adalah penghubung antar dua klik dan inidividu tersebut berada dalam salah satu klik. Pada sentra industri keramik jumlah bridge sebanyak 11 orang yaitu pengrajin nomer 1,2,5,8,9,10,11,13,14, dan16, dalam hal ini 5 orang bridge $(1,2,9,11$,dan16) adalah sekaligus berperan sebagai opinian leader. Liaison adalah individu yang merupakan penghubung antar dua klik tetapi individu tersebut bukan anggota salah satu atau kedua klik. Dalam penelitian ini terdapat satu orang yang berperan sebagai liaison yaitu nomer 23, dalam hal ini dia berperan sebagai broker antara kelompok pengrajin dengan pembeli, yang sering memberikan order pesanan keramik. Dalam pengamatan di lapangan umumnya liaison memiliki hubungan yang luas antar sesama pengrajin, aktif menyebarkan informasi ke pengrajin lainnya dan memiliki hubungan yang baik dengan opinion leader atau ketua kelompok. Hal ini sesuai dengan pendapat Rogers dan Kincaid (1981) bahwa individu yang berperan sebagai liaison atau penghubung dapat mempercepat difusi inovasi dalam suatu sistem.

\section{Derajat Keterhubungan, Integrasi dan Keterbukaan Individu}

Derajat keterhubungan individu dipengaruhi oleh jumlah anggota dalam sistem jaringan. Semakin banyak anggota sistem, maka semakin rendah derajat keterhubungan anggota dalam jaringan. Derajat keterhubungan individu yang tinggi menunjukkan bahwa keterhubungan atau keterkaitan responden melalui hubungan satu arah atau hubungan langsung anggota adalah tinggi. Hal ini berarti bahwa hubungan komunikasi yang terbentuk sangat erat dalam membicarakan pemasaran keramik. Sebaliknya derajat keterhubungan yang 
rendah mengindikasikan bahwa keterhubungan anggota dalam membicarakan pemasaran keramik rendah.

Derajat keterhubungan yang tinggi dimiliki oleh pengrjin responden yang berperan sebagai opinion leader, misalnya ketua kelompok dan opinion leader lainnnya dalam kelompok. Hal ini disebabkan karena ketua kelompok atau pemuka pendapat memiliki pilihan komunikasi langsung yang tinggi dibandingkan dengan anggota lainnya. Disamping itu ketua kelompok merupakan pusat informasi dalam kelompok sebab konsumen yang melakukan order biasanya berhubungan dengan ketua kelompok terlebih dahulu. Hal ini menyebabkan umumnya ketua kelompok mempunyai hubungan langsung yang lebih tinggi dengan anggota-anggota kelompoknya. Distribusi derajat keterhubungan individu disajikan pada Tabel 2.

Tabel 2. Distribusi Variabel Jaringan Komunikasi

\begin{tabular}{|l|l|l|l|}
\hline $\begin{array}{l}\text { Deskripsi Variabel Jaringan } \\
\text { Komunikasi }\end{array}$ & Kategori & Jumlah & Persen \\
\hline \multirow{4}{*}{$\begin{array}{l}\text { Derajat Keterhubungan } \\
\text { Individu }\end{array}$} & Rendah & 3 & 12 \\
\cline { 2 - 4 } & Sedang & 11 & 44 \\
\cline { 2 - 4 } & Tinggi & 11 & 44 \\
\cline { 2 - 4 } & Total & 25 & 100 \\
\hline Derajat Integrasi Individu & Rendah & 4 & 16 \\
\cline { 2 - 4 } & Sedang & 16 & 64 \\
\cline { 2 - 4 } & Tinggi & 5 & 20 \\
\cline { 2 - 4 } & Total & 25 & 100 \\
\hline Derajat Keterbukaan Individu & Rendah & 18 & 72 \\
\cline { 2 - 4 } & Sedang & 4 & 16 \\
\cline { 2 - 4 } & Tinggi & 3 & 12 \\
\cline { 2 - 4 } & Total & 25 & 100 \\
\hline
\end{tabular}

Derajat integrasi individu menunjukkan kekompakan atau keterpaduan sistem. Semakin tinggi derajat integrasi individu, maka tingkat kekompakan atau kepaduan sistem akan semakin kuat. Derajat integrasi individu seperti terlihat pada Tabel 2 menunjukkan bahwa proporsi derajat integrasi individu masih berada pada tingkat sedang. Hal ini menunjukkan bahwa kepaduan individu dalam kelompok masih belum kuat, hal ini disebabkan karena arah komunikasi secara tidak langsung atau dua tahap jumlahnya relatif masih sedikit. 
Model jaringan komunikasi yang terbentuk bersifat memusat (interlocking). Seperti yang terlihat pada sosiogram kelompok pengrajin keramik pada Gambar 2, sebagian besar anggota memilih ketua kelompok sebagai pilihan hubungan komunikasi. Hal ini sesuai dengan pendapat Rogers dan Kincaid (1981) bahwa jaringan personal memusat mempunyai derajat integrasi yang tinggi, dan individu-individu yang terlibat dalam jaringan komunikasi terdiri dari individu-individu yang homophili namun kurang terbuka pada lingkungannya.

Derajat keterbukaan individu menunjukkan tinggi rendahnya hubungan individu dengan orang lain yang profesinya selain pengrajin keramik. Tabel 2 menunjukkan bahwa derajat keterbukaan pada pengrajin keramik masih rendah. Hal ini berarti jumlah responden yang melakukan pertukaran informasi dengan orang lain yang bukan seprofesi masih rendah. Hal ini disebabkan karena anggota-anggota kelompok masih tertutup dengan lingkungan luar, dan diduga anggota kelompok masih merasa lebih yakin dan percaya pada sesama anggota kelompok.

\section{Deskripsi Kegiatan Pemasaran Kerajinan}

Kegiatan Pemasaran Produk Kerajinan dalam penelitian ini dijelaskan pada Tabel 3 . 
Tabel 3. Distribusi Penentuan Jenis Produk

\begin{tabular}{|l|l|l|l|}
\hline $\begin{array}{l}\text { Deskripsi Variabel } \\
\text { Pemasaran }\end{array}$ & Kategori & Jumlah & Persen \\
\hline \multirow{4}{*}{$\begin{array}{l}\text { Tingkat Keragaman Jenis } \\
\text { Produk }\end{array}$} & Rendah & 14 & 56 \\
\cline { 2 - 4 } & Sedang & 8 & 32 \\
\cline { 2 - 4 } & Tinggi & 3 & 12 \\
\cline { 2 - 4 } & Total & 25 & 100 \\
\hline \multirow{4}{*}{$\begin{array}{l}\text { Tingkat Kesepakatan } \\
\text { Harga }\end{array}$} & Rendah & 1 & 4 \\
\cline { 2 - 4 } & Sedang & 8 & 32 \\
\cline { 2 - 4 } & Tinggi & 16 & 64 \\
\cline { 2 - 4 } & Total & 25 & 100 \\
\hline \multirow{4}{*}{$\begin{array}{l}\text { Lingkat Keragaman } \\
\text { Tingkat Keragaman }\end{array}$} & Rendah & 12 & 48 \\
\cline { 2 - 4 } & Sedang & 8 & 32 \\
\cline { 2 - 4 } & Tinggi & 5 & 20 \\
\cline { 2 - 4 } & Total & 25 & 100 \\
\cline { 2 - 4 } & Rendah & 15 & 60 \\
\cline { 2 - 4 } & Sedang & 6 & 24 \\
\cline { 2 - 4 } & Tinggi & 4 & 16 \\
\cline { 2 - 4 } & Total & 25 & 100 \\
\hline
\end{tabular}

\section{Penentuan Jenis Produk}

Penentuan jenis produk yang akan dibuat oleh pengrajin biasanya dilakukan oleh masing-masing pengrajin minimal seminggu sebelum pembuatan. Hal ini mengingat persiapan yang diperlukan membutuhkan waktu lebih dari dua hari. Tingkat keragaman jenis produk menunjukkan tinggi rendahnya pengambilan keputusan untuk menentukan bentuk kerajinan yang akan dibuat yang disesuaikan dengan pengrajin lain yang ada di dalam ruang lingkup sentra industri kecil. Berdasarkan Tabel 3 terlihat bahwa keragaman jenis produk yang dibuat pengrajin masih rendah. Ini menunjukkan bahwa pengrajin kebanyakan memproduksi keramik dengan bentuk yang relatif sama dengan pengrajin-pengrajin lainnya dalam sentra industri kecil di kecamatan Dau. Diduga karena keterhubungan antara pengrajin yang masih tinggi sehingga mereka cenderung memproduksi keramik dalam bentuk yang relatif sama.

\section{Penetapan Harga}

Penetapan harga sangat besar pengaruhnya terhadap tingkat kesejahteraan pengrajin. Karena dengan tingkat harga yang relevan dengan 
biaya produksi akan mempengaruhi tingkat keuntungan yang diperoleh. Hasil yang diperoleh menunjukkan bahwa sebagian besar pengrajin menyatakan bahwa harga ditetapkan berdasarkan kesepakatan pengrajin yang ada dalam kelompok. 64 persen menyatakan bahwa tingkat kesepakatan harga tinggi. Hal ini terkait dengan tingkat keterhubungan diantara pengrajin yang tinggi. Dengan tingkat kesepakatan harga yang tinggi akan dapat menghindari terjadinya konflik antara pengrajin. Namun sisi negatifnya mereka tidak terpacu untuk bersaing dalam memperbaiki mutu, karena dengan mutu seperti yang ada mereka akan memperoleh harga yang sama dengan pengrajin lainnya, karena telah terjadi kesepakatan harga.

\section{Penentuan Lokasi}

Lokasi yang digunakan pengrajin untuk memasarkan produknya dibedakan menjadi dua yaitu di rumah yang sekaligus menjadi show room untuk produknya dan pasar tradisional yaitu pasar disekitar wilayah Kabupaten Malang dan Kota Batu. Hal ini sesuai dengan hasil distribusi penentuan lokasi yang tercantum pada Tabel 3 yang menunjukkan bahwa tingkat keragaman lokasi berjualan produk kerajinan masih rendah, 48 \% responden memiliki kesamaan dalam hal lokasi berjualan yaitu di rumah dan pasar tradisional.

\section{Kegiatan Promosi}

Upaya promosi yang dilakukan oleh pengrajin masih rendah. Tingkat keragaman promosi masih rendah (60\%). Promosi yang telah dilakukan adalah pada pemberian papan nama di depan rumahnya yang menunjukkan bahwa dijual produk kerajinan keramik. Masih sedikit pengrajin yang melakukan kegiatan promosi dengan personnal selling yaitu mendatangan calon pembeli di toko-toko souvenir di kota Malang. Bahkan belum ada pengrajin yang membuat brosur atau katalog produk. 


\section{Hubungan Jaringan Komunikasi Dengan Kegiatan Pemasaran Produk Kerajinan}

Sebagaimana telah dirumuskan sebelumnya bahwa dalam penelitian ini sesuai dengan hipotesis : terdapat hubungan yang nyata jaringan komunikasi (tingkat keterkaitan, tingkat integrasi dan tingkat keterbukaan) dengan kegiatan pemasaran kerajinan (penentuan jenis produk, penetapan harga, penentuan lokasi dan kegiatan promosi)

Terdapat hubungan yang siginifikan antara jaringan komunikasi (tingkat keterkaitan, tingkat integrasi dan tingkat keterbukaan) dengan kegiatan pemasaran kerajinan (penentuan jenis produk, penetapan harga, penentuan lokasi dan kegiatan promosi). Dengan tingkat kepercayaan 95\% diperoleh nilai koefisien tau Kendall 0,863 yang menunjukkan ada hubungan positif yang kuat.

Berdasarkan hasil tersebut dapat diketahui bahwasanya jaringan komunikasi yang ada pada pengrajin keramik memiliki hubungan yang nyata dengan kegiatan pemasaran. Keterhubungan antara pengrajin menjadikan ada rasa senasib sepenanggungan diantara mereka, hal ini terbukti dengan derajat keterhubungan dan derajat integritas yang tinggi dan tingkat kesepakatan harga yang tinggi pula. Di sisi lain derajat integritas yang tinggi tidak menjadikan mereka aktif melakukan kegiatan promosi dan membuat inovasi produk yang lebih beragam serta mencoba memasarkan produk ke lokasi yang lebih luas. Salah satu hal yang menghambat kegiatan pemasaran dapat disebabkan karena derajat keterbukaan pengrajin yang masih rendah, padahal keterbukaan sangat dibutuhkan dalam kegiatan usaha, terutama dalam pemasaran produk kerajinan.

\section{KESIMPULAN}

1. Dilihat dari karakteristiknya, pengrajin keramik di Kecamatan Dau memiliki keragaman pada tingkat pendidikan, tanggungan keluarga dan tingkat penghasilan yang masih rendah. Hal ini disebabkan proses dinamika perkembangan kerajinan yang masih rendah mulai dari pertama kali kerajinan ini tumbuh sampai sekarang. 
2. Jaringan komunikasi terbentuk dari hubungan komunikasi satu arah dan dua arah diantara antar pengrajin dengan memilih satu hingga 5 orang untuk diajak berkomunikasi. Terdapat 7 peran opinian leader, 11 bridge dan satu liaison. Ketua kelompok berperan sebagai opinion leader, disamping itu ada opinion leader yang tidak ditunjuk secara formal oleh kelompoknya dan dianggap sebagai opinion leader oleh anggota-anggotanya. Bridge sebagai penghubung antar dua klik dan berada dalam salah satu klik. Liaison dia berperan sebagai broker antara kelompok pengrajin dengan pembeli, yang sering memberikan order pesanan keramik dan memiliki hubungan yang luas antar sesama pengrajin, aktif menyebarkan informasi ke pengrajin lainnya dan memiliki hubungan yang baik dengan opinion leader atau ketua kelompok. Derajat keterhubungan individu pada pengrajin keramik tinggi dan derajat integrasinya sedang. Namun derajat keterbukaan pengrajin dengan individu di luar klik dan di luar kelompok pengrajin masih rendah.

3. Kegiatan yang dilakukan pengrajin dalam memasarkan produknya masih rendah. Hal ini dapat dilihat dari keragaman jenis produk yang dibuat pengrajin masih rendah, tingkat keragaman lokasi rendah dan tingkat intensitas promosi yang masih rendah. Namun tingkat kesepakatan dalam menentukan harga diantara pengrajin tinggi.

4. Dari hasi uji korelasi dengan analisis korelasi tau Kendall, diketahui bahwa terdapat hubungan yang siginifikan antara jaringan komunikasi (tingkat keterkaitan, tingkat integrasi dan tingkat keterbukaan) dengan kegiatan pemasaran kerajinan (penentuan jenis produk, penetapan harga, penentuan lokasi dan kegiatan promosi). Dengan tingkat kepercayaan 95\% diperoleh nilai koefisien tau Kendall 0,863 yang menunjukkan ada hubungan positif yang kuat.

\section{Saran}

Sesuai dengan hasil analisis data pada penelitian yang telah dilakukan, ada beberapa saran yang dapat diberikan untuk pengembangan pengrajin, khususnya dalam kasus pengrajin keramik di Kecamatan Dau, antara lain: 
1. Perlu ada penyuluhan dan pelatihan bagi para pengrajin khususnya untuk pengrajin yang berpendidikan rendah untuk meningkatkan kemampuan dalam memproduksi keramik, memasarkan keramik dan meningkatkan kemandirian pengrajin

2. Melihat adanya potensi kerajinan keramik untuk meningkatkan pendapatan masyarakat, maka perlu diberikan penyediaan sarana penunjang kegiatan pemasaran dan informasi pemasaran bagi pengrajin.

\section{DAFTAR PUSTAKA}

Bebee SA., Masterson JT., 1994, Communicating in Small Groups: Principles and Practice. Fourth Edition, New York: Harper \& Row Publisher.

BPS, 1995, Profil Industri Kecil dan Kerajinan Rumah Tangga Indonesia Jakarta.

Bird, Mary Jane, 1996, Entrepreneurial Behavior, Singapore, Irwin Mc Graw Hill.

Hubeis, Musa, 1997, Menuju Industri Kecil Profesional di Era Globalisasi Melalui Pemberdayaan Manajemen Industri, Orasi Ilmiah Guru besar Tetap Ilmu Manajemen Industri, Bogor, IPB.

Jahi, Amri, 1993, Komunikasi Massa dan Pembangunan Pedesaan di Negara-Negara Dunia Ketiga, Jakarta, PT Gramedia.

Magginson, William L., Byrd, Mary Jane, Megginson Leon C., 2000, Small Business Management, An Entreprneurs's Guidebook, Singapore, Irwin Mc Graw Hill.

Rogers, EM., Kincaid L, 1981, Communication Network, New York, Mac Millan Publishing Co, Inc.

Rogers, Everett M., Rabel J Burdge, Peter F Korsching, 1983, Diffusion of innovations ( $3^{\text {rd }}$ editions) New York, The Free Press A Division of Mc Millan Publishing Co. Inc.

Singarimbun, M., dan Sofian E., 1987, Metodologi Penelitian Survei, Jakarta, LP3ES.

Setiana, Danny Daud 2001, Membangun Struktur Industri Indonesia yang Kokoh dan Seimbang, Bandung, Jurnal Politea, Vol.1 No.1 
Slamet, Margono, Pemberdayaan Masyarakat, dalam Membentuk Pola Perilaku Manusia Pembangunan, Penyunting Ida Yustina dan Adjat Sudradjat, Bogor, IPB Press.

Umar, 1997, Statistika Untuk Ilmu-Ilmu Sosial, Yogyakarta, BPFE UGM.

*) Hamidah Nayati Utami, Dosen Jurusan Administrasi Bisnis Fakultas Ilmu Administrasi Universitas Brawijaya 